\title{
Tax Reform: the Parts and the Whole
}

Barry Bracewell-Milnes, Banstead

\section{Introduction}

The continuing muddle in British tax policy has lessons for the European Union, where similar confusions prevail at a higher level. Attempts are made to reform parts of an integrated whole as though they were separable. This piecemeal approach to tax reform creates as many problems as it solves: for each door that opens, another closes.

The 1965 classical system of corporation tax was replaced by a partial imputation system in 1972 in the interest of neutrality between dividends and retentions. The 1972 imputation system was abolished in 1997 for pension funds and (from 1999) for individuals below the income-tax threshold and reduced for other taxpayers: this reversion to the classical system was justified as promoting neutrality between dividends and retentions. That two diametrically opposite policies can be defended as moves towards the same kind of neutrality is an indicator of the intellectual incoherence determining policy: it gives a new dimension to the concept of a circular argument.

\section{International and domestic neutrality}

The taxation of domestic income relatively to income from abroad, the taxation of dividends relatively to retained profits, the taxation of gross funds and other charities relatively to individuals and the tax treatment of private welfare provision relatively to state provision are four major elements among those constraining policy towards corporate taxation. If foreign income is taxed more heavily than domestic income, foreign trade and investment are inhibited. If dividends are taxed more heavily than retained profits, the temptation to regard shareholders' money as a cheap source of funds for ventures which would not survive the scrutiny of the market, often strong even under a neutral tax system, becomes overwhelming. If charities like pension funds are denied tax relief on their dividend income, their pensioners are taxed twice, once on the build-up of the fund and a second time on its payout. If private welfare provision is taxed still more heavily by comparison with state welfare provision, pressures on the public purse increase and alleviations of these pressures are enfeebled.

The purpose of introducing partial imputation in 1972 was to prevent the directors of public companies from treating retained profits as a source of cheap captive finance. In this it largely succeeded; but two further problems were generated. First, foreign earnings were put at a disadvantage relatively to domestic earnings as a source of finance for dividend distributions, since advance corporation tax on dividends became a definitive tax if mainstream corporation tax liability was extinguished by international double tax relief. After 18 years of pressure, this problem was resolved in 1994 by the system of Foreign Income Dividends, which enabled qualifying dividends paid out of foreign income to be distributed free of advance corporation tax. The other problem emerged more gradually. A generation ago the majority of publicly quoted shares were held by individuals. Now, the large majority are held by pension funds and other gross funds, which had the advantage of being exempt from the income tax levied on individuals' investment income and the death duties levied on its parent capital. Since the gross funds paid the full rate of corporation tax on retentions but enjoyed partial imputation on distributions, they had an interest in pressing for dividends, and the abolition of their tax credits in the July 1997 Budget could be presented as a move towards neutrality. At the same time the Foreign Income Dividend system was abolished (from 1999) so that dividends financed from overseas earnings once again incur a charge to advance corporation tax from which the same profits are exempt if retained in the company. This is a move away from neutrality and restores the bias against foreign income which characterized the period 1972-1994. It is not only tax rates that compete against each other: so do different forms of tax neutrality.

Similarly, the abolition of the repayment of tax credits from 1999, even at the reduced rate of 10 per cent, means the introduction of a new form of bias against investment income for those below the incometax threshold.

The reduction of the rate of tax credit to 10 per cent represents the unsung European dimension of recent British tax policy. The pre-1997 system of tax credits could be represented as discriminatory against other EU-residents as against residents of the United Kingdom and has been under challenge on these grounds in the courts. The changes in the 1997 Budget conveniently mask a capitulation to this argument.

\section{Government spending and private provision}

Government spending is under pressure in the United Kingdom, as in other industrialized countries. The new 
government has undertaken to respect the short-term spending limits set out by its predecessors.

The most difficult area is welfare spending (health, education and social security, including pensions). The wish of the public for higher standards meets the resistance of the taxpayer to higher taxes. The most obvious answer is the gradual replacement of taxpayer funding with private funding. The argument is of general application and includes health and education; but for the purposes of the present argument, the focus is pensions.

Alarmed by the geometrical rise in projected governmental expenditure on pensions, the previous government took two measures to limit this cost. One was to offer those concerned attractive terms for opting out of the State Earnings Related Pension Scheme. The other, more radical, measure was to restrict the indexation of basic state retirement benefits to prices rather than earnings: if this policy remains in place over several generations of increases in real earnings, state retirement pensions will dwindle into insignificance. These policies have so far enjoyed crossparty support.

Complementary to these constraints on government-funded pension provision was the building up of private provision. A system was in place until the Budget of July 1997 whereby pensions were treated as deferred pay and were taxed (like pay) only once, at the time of receipt. That system has now gone. The build-up of a pension fund invested in company shares is now taxed at the full rate of corporation tax (although the previous, more favourable tax regime is still available for certain property interests and foreign holdings). Thus the alleged pursuit of neutrality between retained and distributed profits has conflicted with neutrality between pay at work and pay in retirement and has compounded the already difficult task of persuading people to make their own provision for old age.

\section{Conclusion}

Much discussion of tax policy takes place on terms which are ultimately futile: the resolution of one problem creates another. Although parts of the tax system (like excise duties) may be separable from the rest, other parts constitute a single, integrated whole which has to be treated as a single entity if any useful conclusion is to emerge. Such are the topics of this editorial - the taxation of domestic income relatively to income from abroad, the taxation of dividends relatively to retained profits, the taxation of gross funds relatively to individuals and the tax treatment of private welfare provision relatively to state provision. The problem is overdetermined in the mathematical sense: there are more equations than variables.

The Institute for Fiscal Studies, London, has noted that investment income, at corporate or individual level, is a more mobile tax base than earning or spending and that for this reason the taxation of investment income is falling in much of the industrialized world relatively to the taxation of earning and spending (which for many taxpayers effectively constitute a single tax base). Since the problems discussed here are worse at higher rates of tax, they are already being mitigated through the pressure of circumstances. Their compete resolution requires the abolition of taxes on individual and corporate income; and in Continuing Tax Reform (1990) the Institute of Directors, London, produced a blueprint for the attainment of this goal over a generation or more without reductions in government spending.

By contrast, more harm than good can be done by the reform of the parts but not the whole; and in these circumstances harmonization can make a bad situation worse. The European Commission once had a proposal for harmonizing corporate tax rates within a band of 45-55 per cent; the United Kingdom rate of corporation tax is now 31 per cent. 